\title{
IDENTIFIKASI KARAKTERISTIK PENDERITA COVID-19 DI PROVINSI NUSA TENGGARA BARAT
}

\author{
Identification of COVID-19 Patient Characteristics in West Nusa Tenggara Province \\ Zaenal Arifin ${ }^{1}$, Melati Inayati Albayani ${ }^{2}$, Baiq Ruli Fatmawati ${ }^{2}$, Marthilda Suprayitna ${ }^{2}$ \\ ${ }^{1}$ Program Studi Pendidikan Ners, STIKES YARSI Mataram, Mataram, NTB, Indonesia \\ ${ }^{2}$ Program Studi Keperawatan, STIKES YARSI Mataram, Mataram, NTB, Indonesia \\ Korespondensi: zn70@gmail.com
}

\begin{abstract}
ABSTRAK
COVID-19 merupakan penyakit infeksi saluran pernafasan yang disebabkan oleh coronavirus yang termasuk betacoronavirus yang berkaitan dengan penyebab Severe Acute Respiratory Syndrome Coronavirus-2. Setelah ditemukan pada akhir tahun 2019 dalam waktu yang relatif singkat COVID-19 telah menyebar di 213 negara dengan jumlah kematian sebanyak 175.825 orang dari 2.549 .632 kasus yang terkonfirmasi. Sedangkan di Indonesia didapatkan jumlah kasus positif COVID-19 sebanyak 7.775 kasus dengan jumlah meninggal sebanyak 647 orang. Tujuan penelitian ini adalah untuk mengetahui karakteristik pasien yang terkonfirmasi positif COVID-19 di Provinsi Nusa Tenggara Barat. Metode penelitian yang digunakan adalah deskriptif dengan pendekatan observasional. Pengambilan data dilakukan dengan menggunakan data sekunder berupa hasil press release dari satgas pencegahan dan penanganan COVID-19 Provinsi Nusa Tenggara Barat periode Mei sampai Juni 2020. Pengambilan sampel dilakukan dengan total sampling dan didapatkan sampel sebanyak 643 sampel. Hasil penelitian menunjukkan bahwa terbanyak pasien pada kelompok umur 26-35 tahun sebanyak 140 orang $(21,8 \%)$, dengan Jenis kelamin laki-laki sebanyak 402 orang $(62,5 \%)$, dan sebagian berasal dari Kota Mataram yaitu sebanyak 235 orang $(36,5 \%)$, yang tidak memiliki riwayat perjalanan dari daerah terkonfirmasi didapatkan 410 orang $(63,6 \%)$, dan yang memiliki riwayat kontak dengan pasien COVID-19 sebanyak 327 orang (50,9\%). Kesimpulan sebagian besar penderita terkonfirmasi positif COVID-19 antara bulan Mei-Juni 2020 di Provinsi Nusa Tenggara Barat paling pada kelompok umur 26-35 tahun, jenis kelamin laki-laki dan memiliki riwayat kontak dengan pasien COVID-19.
\end{abstract}

Kata kunci : Karakteristik, COVID-19, provinsi NTB

\section{ABSTRACT}

COVID-19 is a respiratory tract infection caused by a coronavirus including betacoronavirus which is related to the cause of Severe Acute Respiratory Syndrome Coronavirus-2. After being discovered at the end of 2019 in a relatively short time, COVID-19 has spread in 213 countries with a death total of 175,825 from 2,549,632 confirmed cases. In Indonesia, there were 7,775 positive cases of COVID-19 with 647 people who died. The purpose of this study was to determine the characteristics of patients who were confirmed positive for COVID-19 in West Nusa Tenggara Province. The research method used was descriptive with an observational approach. Data was collected using secondary data in the form of press releases from the West Nusa Tenggara Province COVID-19 prevention and handling task force for the period May to June 2020. Sampling was carried out by total sampling and obtained a sample of 643 samples. The results showed that most patients in the 26-35 years age group were 140 people (21.8\%), with male gender as many as 402 people (62.5\%), and some came from the city of Mataram as many as 235 people (36.5\%), who did not have a travel history from a confirmed area were 410 people (63.6\%), and those who had a history of contact with COVID-19 patients were 327 people (50.9\%). Conclusion: Most of the patients who were confirmed positive COVID-19 between May-June 2020 in West Nusa Tenggara Province were mostly in 26-35 year age group, male and had a history of contact with COVID-19 patients.

Keywords: characteristics, COVID-19, NTB province 


\section{PENDAHULUAN}

Masalah kesehatan yang saat ini masih menjadi fokus perhatian seluruh komponen mulai dari pemerintah pusat sampai ke lapisan masyarakat dan berdampak terhadap seluruh aspek kehidupan adalah penyakit Coronavirus 2019. Penyakit coronavirus 2019 yang selanjutnya disebut dengan COVID-19 ini merupakan penyakit jenis baru yang belum pernah diidentifikasi sebelumnya pada manusia. COVID-19 merupakan salah satu penyakit infeksi saluran pernafasan yang disebabkan oleh virus yang pertama kali ditemukan di Wuhan, Cina pada tahun 2019.

Penyebab COVID-19 adalah virus yang masuk dalam subgenus yang sama dengan coronavirus yang menyebabkan wabah SARS pada 2002-2004 yaitu Sarbecovirus. International Committee on Taxonomy of Viruses (ICTV) memberikan nama penyebab COVID-19 sebagai SARSCoV-2. Coronavirus merupakan zoonosis yang dapat ditularkan antara hewan dan manusia (Kementerian Kesehatan RI, 2020b; WHO, 2020). Sejak ditemukan pertama kali, COVID-19 dengan cepat telah menyebar ke beberepa negara. Adanya penyebaran kasus COVID-19 yang terus meningkat tersebut, WHO telah menetapkan COVID-19 sebagai pandemi (Kementerian Kesehatan RI, 2020a).

Penyebaran COVID-19 berlangsung sangat cepat hal ini dapat dilihat dengan adanya peningkatan angka kejadian atau kasus setiap hari baik secara nasional maupun global. Penyebaran COVID-19 dari individu terinfeksi dapat secara langsung maupun tidak langsung. Penyebaran secara langsung antara lain melalui droplet atau percikan langsung dari jarak 1-2 meter dari orang yang batuk atau bersin tanpa tutup. Sedangkan penyebaran tidak langsung melalui kontak dekat seperti menyentuh dan jabat tangan, menyentuh objek atau permukaan yang terkontaminasi virus, kemudian menyentuh mulut, hidung atau mata sebelum cuci tangan (Burhan, 2020).

Data WHO menunjukkan bahwa COVID-19 telah menyebar di 213 negara dengan jumlah kasus terkonfirmasi positif COVID-19 sebanyak 2.549.632 kasus, dengan jumlah kematian sebanyak 175.825 orang. Sedangkan secara nasional data kasus positif COVID-19 sebanyak 7.775 kasus dengan jumlah meninggal sebanyak 647 orang (Satuan Tugas Penanganan COVID19, 2020).

Penyebaran COVID-19 dapat terjadi pada semua kelompok usia. Infeksi COVID19 dapat terjadi pada neonates, anak, remaja, dewasa dan kelompok lanjut usia. Pada populasi anak memiliki mekanisme penyebaran yang sama dengan kelompok usia lain, dan juga dapat menjadi pembawa virus kepada orang lain (Saleem, Rahman, Aslam, Murtazaliev, \& Khan, 2020). Penyebaran kasus COVID-19 meningkat dengan cepat baik pada anak, remaja, maupun lanjut usia.

Lanjut usia merupakan salah satu kelompok yang paling rentan terhadap penyebaran COVID-19. Peningkatan kasus pada lanjut usia berkaitan dengan tingkat keparahan penyakit terutama pada usia lebih dari 60 tahun yang disertai adanya penyakit penyerta (comorbid) (De Sanctis et al., 2020; WHO, 2020). Hasil penelitian Zhou et al. (2020), didapatkan bahwa penyakit penyerta yang paling banyak dialami pada pasien COVID-19 diantaranya adalah hipertensi, diabetes mellitus dan penyakit jantung koroner.

Terkait status penderita COVID-19, Kemenkes telah menetapkan beberapa istilah yaitu Orang Dalam Pemantauan (ODP), Pasien Dalam Pengawasan (PDP), Orang Tanpa Gejala (OTG). Berdasarkan data data dari Tim Gugus Tugas Pencegahan dan Penanganan COVID-19 Provinsi Nusa Tenggara Barat tanggal 13 April 2020, menunjukkan jumlah Pasien Dalam Pengawasan (PDP) sebanyak 146 orang dengan perincian $60(41 \%)$ PDP masih dalam pengawasan, $86(59 \%)$ PDP selesai pengawasan/sembuh, dan 12 orang PDP meninggal. Untuk kategori Orang Dalam Pemantauan (ODP) jumlahnya 3.812 orang, terdiri dari $1.385(36 \%)$ orang masih dalam pemantauan dan $2.427(64 \%)$ orang selesai pemantauan.

Pasien yang menderita COVID-19 sebagian besar adalah usia dewasa dengan gejala demam, batuk kering dan mengalami sesak nafas. Gejala klinis COVID-19 antara lain demam, kelelahan, batuk, sesak napas 
dan dapat menyebabkan gangguan pernafasan (De Sanctis et al., 2020).

Indonesia merupakan salah satu negara yang terkena dampak COVID-19 telah menyatakan bahwa COVID-19 sebagai bencana kategori bukan disebabkan oleh alam yang berupa wabah penyakit dan telah menetapkan pedoman pencegahan dan penanggulangan. Upaya untuk memutus rantai penularan dan mencegah penyebaran COVID-19 diantaranya dengan mencuci tangan secara teratur, menutup mulut dan hidung ketika batuk dan bersin, memasak daging dan telur dengan seksama, hindari kontak dengan orang yang menunjukkan gejala penyakit pernafasan seperti batuk dan bersin dan melakukan desinfeksi akibat dropley yang menempel pada permukaan (Kementerian Kesehatan RI, 2020c).

Berdasarkan data tentang jumlah penderita COVID-19 menunjukkan bahwa virus corona dapat mengenai semua kelompok usia. Berdasarkan hal tersebut peneliti ingin mengidentifikasi karakteristik penderita COVID-19 di Provinsi Nusa Tenggara Barat khususnya yang terjadi pada rentang waktu mulai bulan Mei sampai dengan Juni 2020 berdasarkan data sekunder (press release) tim gugus tugas pencegahan dan penanganan COVID-19 Provinsi Nusa Tenggara Barat.

\section{TUJUAN PENELITIAN}

Tujuan penelitian ini adalah untuk mengidentifikasi karakteristik pasien COVID-19 di Provinsi Nusa Tenggara Barat.

\section{METODE PENELITIAN}

Desain

Penelitian yang dilakukan merupakan penelitian deskriptif dengan menggunakan pendekatan observasional.

\section{Populasi dan Sampel}

Populasi dalam penelitian ini adalah seluruh pasien yang dikonfirmasi positif mengalami COVID-19 di Provinsi Nusa Tenggara Barat. Teknik pengambilan sampel dilakukan dengan teknik total sampling dan didapatkan sampel sebanyak 643 kasus.

\section{Tempat dan Waktu Penelitian}

Penelitian ini dilakukan di Provinsi Nusa Tenggara Barat. Waktu penambilan data dilakukan sejak Mei sampai Juni 2020.

\section{Instrumen dan Prosedur Pengukuran}

Pengambilan data dilakukan melalui data sekunder hasil press release data COVID-19 periode Mei sampai Juni 2020 dari tim Gugus Pencegahan dan Penanganan COVID-19 Provinsi Nusa Tenggara Barat, yang terdiri dari usia, jenis kelamin, dan riwayat kontak dengan menggunakan lebar observasi.

\section{Analisa Data}

Analisa data yang digunakan pada penelitian ini adalah univariat dengan mencari persentase sebaran data.

\section{HASIL PENELITIAN}

Berikut hasil penelitian yang telah dilakukan analisa univariat:

Tabel 1

Karakteristik Responden Penderita COVID19 di Provinsi NTB $(n=643)$

\begin{tabular}{lcc}
\hline Karakteristik Responden & f & $\mathbf{\%}$ \\
\hline Usia & & \\
$0-5$ tahun & 41 & 6,4 \\
$5-11$ tahun & 15 & 2,3 \\
12-16 tahun & 25 & 3,9 \\
$17-25$ tahun & 85 & 13,2 \\
26-35 tahun & 140 & 21,8 \\
$36-45$ tahun & 138 & 21,5 \\
46-55 tahun & 103 & 16,0 \\
56-65 tahun & 64 & 10,0 \\
> 65 tahun & 32 & 5,0 \\
Jenis Kelamin & & \\
Laki-Laki & 402 & 62,5 \\
Perempuan & 241 & 37,5 \\
Asal Daerah & & \\
Mataram & 235 & 36,5 \\
Lombok Barat & 127 & 19,8 \\
Lombok Utara & 39 & 6,10 \\
Lombok Tengah & 64 & 10,0 \\
Lombok Timur & 65 & 10,1 \\
Sumbawa Barat & 11 & 1,7 \\
Sumbawa & 36 & 5,6 \\
Dompu & 39 & 6,1 \\
Kabupaten Bima & 19 & 3,0 \\
Kota Bima & 3 & 5,0 \\
Luar NTB & 1 & 2,0 \\
\hline
\end{tabular}


Berdasarkan tabel diatas menunjukkan bahwa pasien COVID-19 paling banyak pada kelompok umur 26-35 tahun yaitu sebanyak 140 orag $(21,8 \%)$ dan paling sedikit pada kelompok umur 5-11 tahun yaitu sebanyak 15 orang $(2,3 \%)$. Pasien COVID-19 yang berjenis kelamin laki-laki lebih banyak yaitu sebanyak 402 orang $(62,5 \%)$ dibandingkan dengan perempuan yaitu 241 orang $(37,5 \%)$. Asal dari pasien COVID-19 paling banyak adalah dari Kota Mataram yaitu 36,5\%.

Tabel 2

Faktor Resiko Positif COVID-19 (n-643)

\begin{tabular}{lcc}
\hline $\begin{array}{c}\text { Faktor Resiko Positif } \\
\text { COVID-19 }\end{array}$ & f & $\mathbf{\%}$ \\
\hline $\begin{array}{l}\text { Riwayat Perjalanan Luar } \\
\text { Daerah }\end{array}$ & & \\
$\quad Y a$ & 233 & 36,2 \\
$\quad$ Tidak & 410 & 63,6 \\
Riwayat Kontak dengan & & \\
Pasien COVID-19 & & \\
$\quad Y a$ & 327 & 50,9 \\
$\quad$ Tidak & 314 & 48,8 \\
\hline
\end{tabular}

Berdasarkan tabel diatas menunjukkan bahwa pasien COVID-19 paling banyak adalah pasien yang tidak memiliki riwayat perjalanan ke atau dari daerah yang terkonfirmasi COVID-19, yaitu sebanyak 410 orang $(63,6 \%)$. Pasien COVID-19 yang memiliki riwayat kontak dengan pasien terkonfirmasi positif COVID19 lebih banyak yaitu 327 kasus (50,9\%) dibandingkan dengan pasien yang tidak memiliki riwayat kontak.

\section{PEMBAHASAN}

Berdasarkan data hasil identifikasi karakteristik pasien yang menderita COVID19 di Provinsi Nusa Tenggara Barat berdasarkan umur didapatkan terbanyak pada kelompok umur antara 26 sampai dengan 55 tahun yaitu sebanyak 381 orang (59.2\%). Sejak ditemukan sampai saat ini jumlah kasus COVID-19 terus mengalami peningkatan dan terjadi pada semua kelompok usia. Data WHO menunjukkan bahwa COVID-19 banyak terjadi pada kelompok usia dewasa sampai dengan kelompok lanjut usia (lansia).
Hasil identifikasi kasus COVID-19 menurut usia mengacu jumlah pasien COVID-19 pada bulan Mei dan Juni 2020 didapatkan bahwa kasus terkorfirmasi COVID-19 terbanyak pada kelompok usia 26 sampai dengan usia 55 tahun yaitu sebanyak 381 orang (59.2\%). Data tersebut menunjukkan bahwa kasus COVID-19 di Provinsi Nusa Tengara Barat paling banyak terjadi pada kelompok usia dewasa dan lansia. Lansia merupakan salah satu kelompok yang paling rentan terpapar COVID-19 terutama lansia yang disertai dengan penyakit penyerta (Kementerian Kesehatan RI, 2020a).

Perubahan sistem imun dipengaruhi oleh beberaoa faktor yaitu lingkungan, makanan, kondisi kesehatan, obat-obatan dan usia. Kemampuan tubuh melawan infeksi mengalami penurunan seiring peningkatan usia. Peningkatan usia dapat disertai dengan adanya penurunan fisiologis sistem imun. Penurunan imunitas pada usia lanjut diantaranya akibat berkurangnya produksi immunoglobulin (Sasmito et al., 2020). Peningkatan usia juga dapat diikuti adanya penurunan produkai sel $\mathrm{T}$. Sel $\mathrm{T}$ disimpan dalam kelenjar getah bening dan juga di dalam limpa dan sel B sumsum tulang untuk sel B. Kelenjar getah bening bertanggungjawab atas pemeliharaan dan koordinasi respon imun baru yang diperlukan untuk mengendalikan virus diantarnta SARS-2 (Nikolich-Zugich et al., 2020).

Berdasarkan hasil analisis didapatkan bahwa kasus terkonformasi COVID-19 di Provinsi Nusa Tenggara Barat lebih banyak terjadi pada laki-laki yaitu sebesar $62.5 \%$ dibandingkan dengan dengan perempuan (37.5\%). Tingginya kasus COVID-19 pada laki-laki dapat dipengaruhi oleh beberapa faktor diantaranya adalah faktor hormonal, kebiasaan dan gaya hidup. Adanya perbedaan fisiologis dalam sistem imun antara laki-laki dan perempuan mempengaruhi kemampuan tubuh dalam menghadapi infeksi termasuk respon terhadap infeksi virus SARS-2-Cov2. Perempuan lebih resisten terhadap infeksi jika dibandingkan dengan laki-laki, hal ini dapat disebabkan faktor hormon seks dan 
ekspresi reseptor coronavirus (ACE-2) yang lebih tingi pada laki-laki (Biswas, 2020).

Selain itu faktor hormonal, tingginya kasus COVID-19 pada laki-laki dapat dipengaruhi oleh kebiasaan dan perilaku. Menurut Bwire (2020), perempuan cenderung memiliki sikap yang lebih bertanggung jawab terhadap pandemi COVID-19 dibandingkan laki-laki dalam melakukan upaya pencegahan sepertti sering mencuci tangan, memakai masker wajah, dan tetap di rumah. Berdasarkan hasil penelitian menunjukan bahwa sebagian besar(50,9\%) penderita COVID-19 yang dinyatakan positif COVID-19 memiliki riwayat kontak dengan pasien yang terkonfirmasi positif sebelumnya. Menurut WHO (2020), transmisi SARS-CoV-2 dapat terjadi melalui kontak langsung, kontak tidak langsung, atau kontak erat dengan orang yang terinfeks. Penularan dapat melalui sekresi seperti air liur dan sekresi saluran pernapasan atau droplet dari orang yang terinfeksi. Hasil studi literatur oleh Nugroho, C. Indah, Alanish S T, Istiqomah, \& Cahyasari (2020), menyebutkan bahwa penularan coronavirus 2019 antar manusia dapat terjadi karena adanya hubungan yang dekat yaitu keluarga, teman atau kontak dengan orang yang telah terkonfirmasi positif COVID-19.

Menurut Galbadage, Peterson, \& Gunasekera (2020), SARS-Cov 2 dapat bertahan lama rata-rata 6,8 jam pada permukaan plastik dan 5,6 jam pada permukaan logam dan partikel virus dapat bertahan sampai 72 jam setelah terpapar. Hasil studi tersebut menunjukan bahwa SARS-Cov2 dapat bertahan lama jika dibandingkan dengan virus lain yang ditularkan melalui droplet. Berdasarkan gambaran terebut memperkuat penjelasan hasil identifikasi bahwa sebagian besar penderita yang terkonfirmasi positif COVID-19 di Provinsi Nusa Tenggara Barat pada bulan Mei-Juni 2020 pernah kontak dengan penderita yang telah dinyatakan positif COVID-19.

\section{KESIMPULAN \\ Implikasi}

Berdasarkan hasil penelitian tentang karakteristik pasien COVID-19 di Provinsi
Nusa Tenggara Barat didapatkan bahwa sebagian besar pasien pada kelompok umur 26-35 tahun, terbanyak terjadi pada laki-laki dengan sebagian besar memiliki riwayat kontak dengan penderita yang telah dinyatakan positif COVID-19. Penerapan modifikasi menjaga jarak dengan orang yang sakit menjadi sangat penting, dengan mengesampingkan stigma kepada penderita COVID-19.

\section{Keterbatasan}

Pengambilan data dilakukan pada melalui data sekunder sehingga menambah periode waktu penelitian yang lebih panjang.

\section{DAFTAR PUSTAKA}

Biswas, R. (2020). Are Men More Vulnerable to Covid-19 as Compared to Women? Journal of Scientific \& Technical Research, 27(2), 2064520646.

Burhan, E. (2020). Coronavirus Disease 2019. Jakarta.

Bwire, G. M. (2020). Coronavirus: Why Men are More Vulnerable to Covid-19 Than Women? SN Comprehensive Clinical Medicine, 2(7), 874-876.

De Sanctis, V., Ruggiero, L., Soliman, A. T., Daar, S., Di Maio, S., \& Kattamis, C. (2020). Coronavirus disease 2019 (Covid-19) in adolescents: An update on current clinical and diagnostic characteristics. Acta Biomedica, 91(2), 184-194.

Galbadage, T., Peterson, B. M., \& Gunasekera, R. S. (2020). Does COVID-19 Spread Through Droplets Alone? Frontiers in Public Health, 8.

Kementerian Kesehatan RI. (2020a). Hindari Lansia Dari COVID 19. Retrieved from http://www. padk.kemkes.go.id/ article/read/2020/04/23/21/hindarilansia-dari-covid-19. html

Kementerian Kesehatan RI. Keputusan Menteri Kesehatan Republik Indonesia Nomor HK.01.07/MenKes/413/2020 Tentang Pedoman Pencegahan dan Pengendalian Corona Virus Disease 2019 (Covid-19), Pub. L. No. HK.01.07/MenKes/413/2020, MenKes /413/2020 (2020). Indonesia.

Kementerian Kesehatan RI. (2020c). 
Pedoman Pencegahan dan Pengendalian Corona Virus deases (Covid-19). Kementrian Kesehatan (1st ed.). Jakarta: Kementerian Kesehatan RI.

Nikolich-Zugich, J., Knox, K. S., Rios, C. T., Natt, B., Bhattacharya, D., \& Fain, M. J. (2020). SARS-CoV-2 and COVID-19 in older adults: what we may expect regarding pathogenesis, immune responses, and outcomes. GeroScience, 42(5), 1225-1227.

Nugroho, W. D., C. Indah, W., Alanish S T, Istiqomah, N., \& Cahyasari, I. (2020). Literature Review: Transmisi Covid19 dari Manusia ke Manusia Di Asia. Jurnal of Bionursing, 2(2), 101-112.

Saleem, H., Rahman, J., Aslam, N., Murtazaliev, S., \& Khan, S. (2020). Coronavirus Disease 2019 (COVID19) in Children: Vulnerable or Spared? A Systematic Review. Cureus, 2019(5), 1-10.

Sasmito, E., Ikawati, M., Sahid, M. N. A., Fakhrudin, N., Ikawati, Z., \& Murwanti, R. (2020). Perlunya Peningkatan Sistem Imun pada Pandemi COVID-19. Retrieved from https://farmasi.ugm.ac.id/id/perlunyapeningkatan-sistem-imun-pada-pande mi-covid-19/

Satuan Tugas Penanganan COVID-19. (2020). Data Sebaran. Retrieved from https://covid19.go.id/

WHO. (2020). WHO Coronavirus Disease (COVID-19) Dashboard | WHO Coronavirus Disease (COVID-19) Dashboard. Retrieved from https://covid19.who.int/

Zhou, F., Yu, T., Du, R., Fan, G., Liu, Y., Liu, Z., ... Cao, B. (2020). Clinical course and risk factors for mortality of adult inpatients with COVID-19 in Wuhan, China: a retrospective cohort study. The Lancet, 395(10229), 10541062. 